\title{
UNIVERSITY OF REGINA TO PURCHASE HERBARIUM COLLECTION
}

The Fort Qu'Appelle Herbarium started as a private Herbarium in 1956 with coleections from the Qu'Appelle Valley. By 1959 the vascular plant collection had expanded to 2,000 specimens. A Cryptogamic Harbarium was started in 1961 which to date has about 2,000 of mosses and lichens. By 1973 the Herbarium had 6,000 fully documented vascular specimens stored in cabinets. It was at that time that a submission was made under sponsorship of the Saskatchewan Natural History Society, Fort Qu'Appelle Branch, for recognition as an International Herbarium. This was granted in 1974 and the Fort Qu'Appelle Herbarium $(\mathrm{FQH})$ was listed in the Index Herbariorum Part I, the Herbaria of the World.

To date the vascular plant collection has reached the 10,000 specimens representing as its main component collections from the Qu'Appelle Valley and other parts in Saskatchewan. Other collections are from northwest Ontario, southwest Alberta and the Canadian Arctic, with lesser collections from western Manitoba, British Columbia and Europe.

Voucher specimens from botanical studies in the Hasbala Lake Region in northeast Saskatchewan, the Qu'Appelle Valley, Abandoned Railroads in southeast Saskatchewan and specialized plant studies in Saskatchewan as well as botanical investigations in the Cypress Hills and Writing-on-Stone Provincial
Park in Alberta, are deposited in the Herbarium.

First collections for Saskatchewan such as: Cicer arietinum, Malva sylvestris var. mauritiana, Lathyrus sativus, Alyssum alyssoides, Delphinium bicolor f. DeVriesii, and Epilobium alpinum a first for the Cypress Hills complex with additional first collections for Canada, Alberta and British Columbia as well as rare plants, adds to the scientific value of this Herbarium.

To house and maintain the Herbarium has become increasingly difficult. For this and other reasons the entire Herbarium was for sale to the University of Regina to be permanently housed in their Herbarium.

To this purpose the Univeristy of Regina has set up a "Herbarium Fund" to receive donations for which tax charity donations receipts will be given. It is hoped that in this way the acquisition of the Fort Qu'Appelle Herbarium becomes a reality, as it will increase the scientific value of the existing Herbarium leading to a better understanding of our native Flora.

A plea for donations is always a sensitive task, but friends of the Herbarium can understand the difficulties to move and permanently house the collection and any amount will greatly be appreciated. 